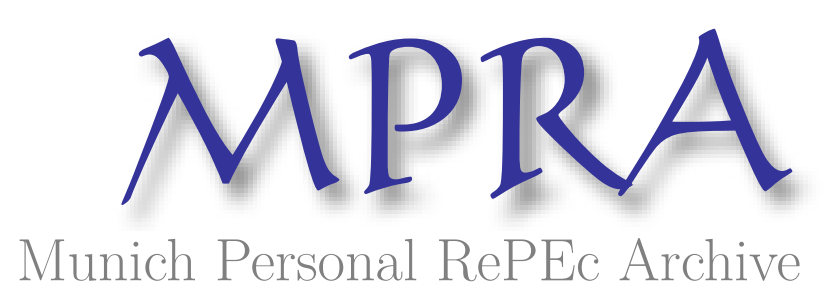

\title{
UK Financial Reforms: Bank of England 2.0
}

Lopez, Claude and Saeidinezhad, Elham

Milken Institute, Milken institute

2016

Online at https://mpra.ub.uni-muenchen.de/76624/

MPRA Paper No. 76624, posted 06 Feb 2017 12:59 UTC 


\section{UK Financial Reforms: Bank of England 2.0}

Claude Lopez and Elham Saeidinezhad 


\title{
UK Financial Reforms: Bank of England 2.0
}

\author{
Claude Lopez ${ }^{1}$ and Elham Saeidinezhad ${ }^{2}$
}

A few months ago, we produced a timetable for the implementation of U.S. financial reform under the Dodd-Frank Act. ${ }^{3}$ One of the main observations was that the legislation did little to consolidate regulation outside of banking. In contrast, the analogous UK reform legislation, the Financial Services Act, made the Bank of England (BoE) the center of UK financial and monetary stability. A 2016 amendment confirmed and strengthened the bank's role.

However, a significant number of UK financial rules are based on European Union regulations, and currently, as a member of the single market, the UK is subject to them. That membership also has given Britain a voice in EU rule making through representation in both the European Parliament and the Council of Ministers. The UK implements EU rules either by transposing EU directives into British law or by directly enforcing EU regulations. These differences are important, especially as Britain and the EU prepare for the approaching Brexit: To maintain the current regulatory framework, the UK will have to transpose all the EU regulations into its national law. This is even more important now with the EU's increased usage of regulations as the final stage of the Basel III accord's implementation approaches. Furthermore, the EU's regulatory framework itself is a work in progress, with key deadlines in 2018 and 2019. Forsaking EU membership will limit the UK's ability to influence this process, although it may be obligated to follow the rules that result, because they are mostly driven by international regulatory efforts that include non-EU countries such as the U.S.

Before assessing these challenges, this paper establishes a timeline summarizing the status of financial regulatory reform in the UK. It then identifies some of the forthcoming difficulties, including Brexit and the recent evolution of macroprudential policies among developed countries.

\section{Milestone Timeline}

In response to the global financial and European sovereign debt crises, as well as the Libor scandal, the UK fundamentally reformed its regulation of financial services. This new framework, presented in the Financial Services Act 2012, makes the Bank of England responsible for financial stability and places a strong emphasis on macroprudential policy. Monitoring systemically important institutions, markets, and activities is at the core of the act, the UK implementation of the Basel III accord. ${ }^{4}$ The act focuses on four main issues: strengthening financial stability via enhanced prudential rules; identifying and

\footnotetext{
${ }^{1}$ Claude Lopez, PhD, leads the International Finance and Macroeconomics research team at the Milken Institute, clopez@milkeninstitute.org

${ }^{2}$ Elham Saeidinezhad, PhD, is a research economist on the team.

${ }^{3}$ Lopez and Saeidinezhad (2016).

${ }^{4}$ http://www.bankofengland.co.uk/financialstability/Pages/default.aspx.
} 
monitoring systemically important financial institutions (SIFIs) and providing orderly resolution when necessary; increasing consumer protection and promoting competition; and enhancing the integrity of markets, including derivatives dealing and pension fund activities.

Table 1, on page 10 , shows the goals and implementation dates of the main regulatory changes in the UK We discuss these changes chronologically below.

\section{2}

As noted, 2012 was a turning point for the UK regulatory architecture. The Financial Services Act completed the regulatory structural reform by abolishing the UK Financial Service Authority and creating three new financial regulators: the Financial Conduct Authority (FCA), the Prudential Regulation Authority (PRA), and the Financial Policy Committee (FPC). As shown in Figure 1, the BoE houses the PRA and the FPC. The new regulators' mission is to identify, prevent, and, if necessary, respond quickly to financial stability issues.

\section{Figure 1. Regulatory Architecture of UK}

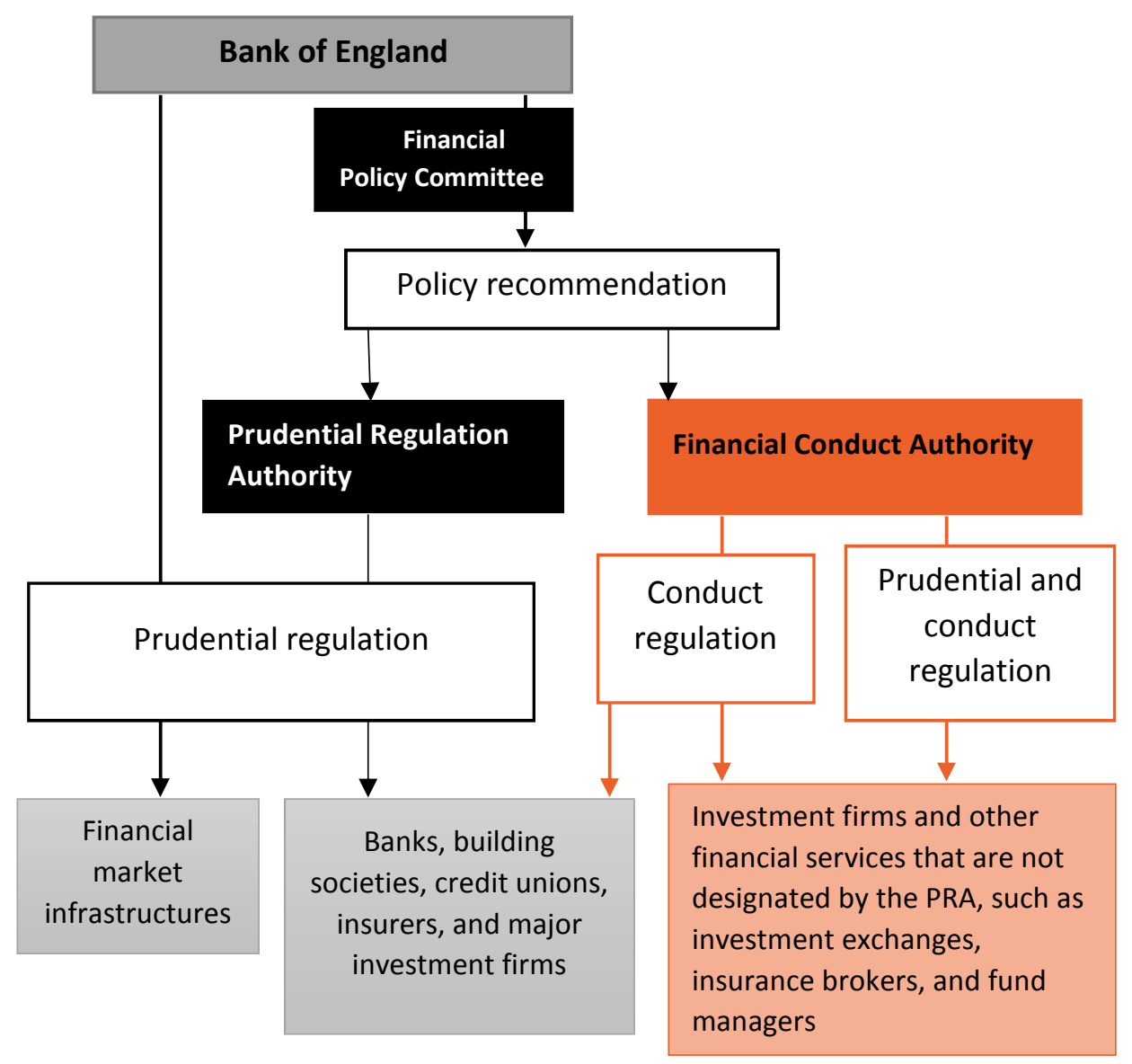

2013

Under the authority of the Financial Services (Banking Reform) Act, the government implements several new banking regulations, many driven by Basel III. As a result, the BoE/PRA uses size, 
interconnectedness, complexity, and business type as criteria to sort all national deposit-takers, investment firms, and insurers into five categories reflecting their potential impact on the financial system. Regulatory stringency is based on the degree of risk posed by each category, with the first category consisting of institutions whose failure would significantly disrupt the UK financial system. ${ }^{5}$ The concept of "ring fencing" is introduced this year. Large deposit-takers should ring-fence, or insulate, their investment banking activities from their retail operations. In contrast with the Volcker Rule in the U.S., the UK approach does not require ring-fenced bodies to be a separate legal entity from the group that engages in excluded activities. Instead, they must be sufficiently independent of this group. However, it is only in 2016 that the BoE/FPC provide some guidance regarding ring fencing's implementation, with 2019 being the target implementation date.

Furthermore, key EU directives and regulations start being transposed, or converted into British law, and implemented to improve market integrity and security dealing. These include the European Market Infrastructure Regulation (EMIR), which regulates the derivatives market, in particular OTC derivatives, central counterparties (CCPs), and trade repositories; the Alternative Investment Fund Managers Directive (AIFMD), which regulates hedge funds, private equity, and real estate funds; and the Financial Conglomerates Directive, which focuses on large financial groups active in different financial sectors, often across borders, and promotes convergence in national supervisory approaches and between sectors. The BoE, in charge of the supervision of financial market infrastructure (FMI), relies on directly applicable EU regulations, accompanied by binding technical standards for the supervision of CCP and securities settlement systems. ${ }^{6}$

Finally, two other notable reforms focus on consumer protection. The Mortgage Market Rule gives the FCA power to regulate mortgage activity and to act upon poor practices where they emerge; the Temporary Product Intervention Rule empowers the FCA to intervene temporarily in the financial market if consumer protection is needed urgently, without seeking public comment.

\section{4}

In 2014, the BoE/FPC implements the second phase of the SIFIs framework and publishes the first result of stress testing for the UK banking system. ${ }^{7}$

Furthermore, financial governance within the EU is strengthened and harmonized by the creation of a "single rulebook," which applies to the financial sector across the entire European Union, with the aim of enhancing financial market transparency and integrity. The provisions of the single rulebook are set out in three main legislative acts:

\footnotetext{
${ }^{5}$ The BoE/PRA prudentially supervise banks, insurers and systemically important investment firms. The FCA is prudentially supervisor of all other financial firms.

${ }^{6}$ These UK and EU regulations and standards in turn follow global standards drawn up by central banks and securities market regulators working together through the Committee on Payment and Settlement Systems (CPSS) and the International Organization of Securities Commissions (IOSCO).

${ }^{7}$ The Committee of European Banking Supervisors ran EU-wide stress tests in 2009 and 2010. Starting in 2011, the European Banking Authority has been running EU-wide stress tests every two years.
} 
- Capital Requirements Regulation and Directive (CRD IV), which implements the Basel III capital requirements for banks. The CRD must be implemented through national law, whereas the Capital Requirements Regulation (CRR) is directly applicable to firms across the EU. ${ }^{8}$

- Bank Recovery and Resolution Directive (BRRD), which establishes a harmonized framework for the recovery and resolution of credit institutions and investment firms found to be in danger of failing.

- Deposit Guarantee Scheme Directive (DGSD), which regulates deposit insurance in case of a bank's inability to meet its liabilities.

CRD IV was implemented in the UK in 2014 and DGSD and BRRD were implemented in 2015.

The Financial Stability Information Power also enables the BoE/PRA "to require a person to provide information or documents relevant to the stability of one or more aspects of the UK financial system. "I9 At the same time, the FCA expanded its supervisory authority to all firms, financial or nonfinancial, that provide consumer credit. It also pushes legislation, such as the Client Assets Regime for Investment Business (CASS), to improve competition and regulatory transparency while protecting investors. ${ }^{10}$

\section{5}

In 2015, the BoE/PRA and FCA publish their final rules regarding the last step of the SIFls framework: recovery and resolution planning. The SIFIs supervision is extended to the insurance industry at the European level, with the implementation of the Solvency II Directive scheduled for 2016. In anticipation, the BoE/PRA performs the first general insurance stress testing. ${ }^{11}$

Several major EU rules, mostly related to conduct in an effort to increase transparency and investor and consumer protection, are transposed into UK law. These include the Markets in Financial Instruments Directive II (MiFID), which, with the accompanying Regulation Markets in Financial Instruments Regulation (MiFIR) and technical standards-collectively MiFID II-build on and extend the scope of MiFID I that created a single market for investment services and activities. ${ }^{12}$ However, its implementation date is later delayed to 2018.

\footnotetext{
${ }^{8}$ Most capital requirement aspects of CRD IV, such as minimum capital requirements and capital buffer requirements, have already become binding legislation. Liquidity requirements, i.e., the liquidity coverage ratio (LCR) and the net stable funding ratio (NSFR), are still a work in progress, with full implementation planned by 2018. Leverage ratios are expected to be reported by the end of 2016, with legislation to make it a binding measure-if necessary-as of 2018.

9 Prudential Regulation Authority (2014, p. 3).

${ }^{10}$ The UK Treasury transferred credit consumer regulatory authority to the FCA. While most of the rules took effect in 2014, the transitional period for certain prudential requirements on debt management ends in 2017.

11 The European Insurance and Occupational Pensions Authority (EIOPA) started its first sets of EU-wide stress tests in 2011. It grew to be part of the implementation of Solvency II, in 2015, and included 50\% of insurance companies per country. Starting in 2015, PRA conducts a general insurance stress test exercise for all Category 1 and 2 UK-regulated general insurers as part of the act. Additional, major UK insurers go through EU-wide EIOPA stress tests.

12 https://www.esma.europa.eu/policy-rules/mifid-ii-and-mifir.

13 UCITS $V$ also harmonizes the administrative regimes for mutual funds across the EU.
} 
Many of the 2016 changes focus on improving market integrity and increasing consumer and investor protection. The implementation of pension reforms forces significant changes in the pensions and retirement income market. The reforms reflect the FCA's goal of ensuring that consumers have access to products and services that are well governed and deliver value within open, competitive, and innovative markets. The reforms require firms to make significant operational and technical changes. This period of change will continue in 2017 with the introduction of a secondary annuity market.

Other changes such as the Senior Managers Regime, Senior Insurance Managers Regime, and Undertakings for Collective Investment in Transferable Securities Directive (UCITS V) focus on strengthening personal accountability for the management of designated firms. ${ }^{13}$ The Bank of England and Financial Services Act expands the notion of enhanced accountability to all firms. This last piece of legislation confirms and reinforces the central place of the Bank of England in terms of monetary and financial stability.

\section{The Road Ahead}

Nearly a decade after the global financial crisis, the implementation of UK financial reform remains a work in progress. Furthermore, recent international developments, from Brexit to the potential of diverging macroprudential and monetary policy among leading economies, such as the U.S. and Europe, threaten to weaken resolve to implement worldwide coordinated financial policy.

As noted above, implementation dates are approaching for many of the regulations. For banking reform, the last step of the SIFIs approach, recovery and resolution, requires the BoE to establish the Minimum Requirement for Own Funds and Eligible Liabilities (MREL) regime to ensure that firms have sufficient capacity to absorb losses, so that their failure would not disrupt the larger economy. In November 2016, the BoE set MREL's technical standards and extended full implementation to 2022, with the exception of "global systemically important banks," which must meet the FSB's total loss-absorbing capacity by 2019. Implementation of the ring-fencing rule also is planned for 2019.

Similarly, for the nonbanking sector, major reforms either have a forthcoming implementation date or are still at a negotiation/design stage. The European money market fund reform has yet to become law, while significant reforms to stabilize activities in the capital markets, such as EMIR and MiFID II, are a work in progress; although EMIR has already come into force, technical requirements that are key to its implementation aren't complete. Furthermore, the implementation date for MiFID II has been delayed until January 2018. These two regulations, combined with the Central Securities Depositories Regulation (CSDR), are the three pillars of a framework to regulate systemically important securities infrastructures. CSDR came into force in 2014; however, many of the requirements will not apply until technical standards become UK law. Finally, while central counterparties (CCPs) are the form of financial market infrastructure (FMI) that have attracted the most attention from regulators, securities settlement systems are key to reducing credit and liquidity risk, especially during market distress, and very little has been done to address the problem. ${ }^{14}$

\footnotetext{
13 UCITS $V$ also harmonizes the administrative regimes for mutual funds across the EU.

${ }^{14}$ The system helps ensure that payments accompany deliveries of securities. It thereby reduces liquidity risk and credit risk by decreasing the chance that deliveries or payments would be withheld during periods of financial stress.
} 
The timing of these implementations coincides with the timeline for Brexit. As noted above, the UK regulatory system relies heavily on EU rules that, as an EU member, the UK helped design. Beyond removing the UK's voice and expertise in influencing future policies, Brexit will have a direct impact on existing processes. These include "passporting" and clearing euro-denominated derivatives. Changes to either could cause significant disruption for both the UK and EU.

Passporting: This refers to the ability of any financial firm registered in one of $28 \mathrm{EU}$ states, plus Iceland, Liechtenstein, and Norway, to operate throughout the entire region without any additional authorization. Furthermore, it makes the process more efficient thanks to features such as home state supervision, which reduces regulatory burdens. It also allows exemptions from local regulatory deposit requirements, which decrease costs by enabling British firms to run relatively large international businesses as branches rather than as separately capitalized subsidiaries. Passporting is essential to some of the current regulations such as MiFID and CRD IV. Its demise would have a significant impact, especially for banking, since about a fifth of the UK banking sector's annual revenue depends on it. ${ }^{15}$ As currently defined, passporting rights are linked directly to EU single-market membership, again with the exceptions of Norway, Iceland, and Liechtenstein.

Euro-denominated derivatives clearing: About 75 percent of European trading in euro-denominated interest-rate swaps, a major type of derivative, takes place in the UK, compared with 13 percent in France and 2 percent in Germany. ${ }^{16}$ In 2015, the European Court of Justice strengthened London's role in derivatives clearing by ruling against the European Central Bank (ECB) requirement for CCPs involved in securities clearing to be within the euro zone. The court specified that "the ECB does not have the competence necessary to impose such a requirement" and that location was not a requirement of the Treaty on Functioning of the European Union. ${ }^{17}$ Besides the expertise of clearinghouses such as LCH, a key component for this ruling was the UK's membership in the EU.

Finally, the success of financial regulation in mitigating systemic risk ultimately relies on international coordination. Such coordination, and subordination of national specificities, came easily amid the urgency of the financial crisis and its immediate aftermath. Since then, differing rates of recovery and the expectation of diverging monetary policies have refocused regulators' attention on their countries' individual needs.

Divergence in macroprudential policy and international coordination: The erosion of international policy coordination is particularly notable in banking. In the days following the Brexit vote, the BoE/FPC announced the loosening of some of the newest macroprudential requirements in order to strengthen the resilience of UK banks in anticipation of heightened economic uncertainty. ${ }^{18}$ In September, the

\footnotetext{
${ }^{15}$ Scarpetta and Booth (2016) estimate that around a fifth of the UK banking sector's annual revenue depends on passporting, compared with around $11 \%$ of the insurance market gross written premium and $7 \%$ of the asset managed in the UK They also discuss the limitation of existing alternatives to passporting, such as equivalence and negotiating bespoke deals and local arrangements.

${ }^{16}$ Bank for International Settlements statistics (April 2016).

17 General Court of the European Union (2015).

${ }^{18} \mathrm{FPC}$ loosened its macroprudential standards by excluding central bank reserves from the exposure measure in the current UK leverage ratio framework. It also reduced the UK countercyclical capital buffer rate for the largest banks and allowed insurance
} 
European Commission hinted that it might not accept the final stage of Basel III reforms, saying, "[We] need an intelligent solution which takes account of the individual banks' situations and maintains a risksensitive approach to setting capital requirements. Different banks have different business models which involve different levels of risk." ${ }^{19}$ At the same time, the U.S. Federal Reserve is supportive of more stringent measures in the last stage. ${ }^{20}$

Difficult negotiations between the EU and the U.S. are not new. Reaching an agreement to accept one another's derivatives rules took three years, a lengthy negotiation considering that a lack of convergence would have been quite disruptive to the derivatives market. Yet, when it comes to banking regulation, the differences may be even more deeply ingrained in regional specificities. The EU and the UK rely heavily on banks. More than 90 percent of corporate debt in Europe consists of bank loans, with less than 10 percent coming from the corporate bond markets. Lending in the U.S. is more balanced. ${ }^{21}$ Furthermore, large European banks historically have been global leaders in cross-border lending. As a result, their business model, which often includes a relatively strong international exposure, may appear less threatening to European regulators than to their U.S. counterparts. The European commissioner in charge of the Financial Stability, Financial Services and Capital Markets Union, in line with many European regulators, has recently emphasized a conceptual difference in the context of finalizing Basel III: "It is perfectly normal for a bank focused on lending in a sector and region with low risks to have lower average risk weights than a bank operating elsewhere."

When it comes to financial regulations, it matters very little whether the UK is part of the EU, as the new regulatory framework is an international initiative. Basel III and its attempt to standardize information sharing and assessment methods enabled more rigorous monitoring of the banking sector. Ultimately, the Basel reforms should also avoid divergence of requirements and minimize the compliance burden across jurisdictions, geographic or otherwise (domestic SIFIs versus global SIFIs).

However, this harmonized regulatory framework applies to countries that have different economic performances, monetary policy, and financial markets. As a result, while it makes monitoring more efficient, it does not imply that the appropriate policy response should be the same across countries. In other words, different business models between large U.S. and European banks or between industries, such as asset managers and banks, require different policy choices, even in terms of macroprudential policy.

companies some flexibility in Solvency II regulations when recalculating transitional measures. See records of FPC meetings for June 25, July 12 and September 20.

19 Dombrovskis (2016).

20 Tarullo (2016).

${ }^{21}$ Based on BIS data, the composition of EU, UK and U.S. bank loan (debt issuance) can be approximate; 90 (10), 71 (29) and 56 (44) percent, respectively, Wright (2015). 
Table 1. Goals and implementations ${ }^{22}$

\begin{tabular}{|c|c|c|c|}
\hline Financial stability & Targeted outcome & Target & Implementation \\
\hline Financial Services Act & $\begin{array}{l}\text { Implement a new regulatory } \\
\text { framework }\end{array}$ & $\begin{array}{l}\text { Financial system and } \\
\text { financial services }\end{array}$ & 2012, 2013, and 2017 \\
\hline $\begin{array}{l}\text { Prudential rules, such as } \\
\text { Requirements Directive IV } \\
\text { (CRD IV) }\end{array}$ & $\begin{array}{l}\text { Implementation of Basel III's } \\
\text { prudential regulation }\end{array}$ & $\begin{array}{l}\text { Banks, building } \\
\text { societies, and } \\
\text { investment firms }\end{array}$ & $\begin{array}{l}\text { January 2014, with full } \\
\text { implementation in } \\
\text { January } 2019\end{array}$ \\
\hline Solvency II Directive & $\begin{array}{l}\text { Harmonize EU insurance } \\
\text { regulation }\end{array}$ & Insurers & $\begin{array}{l}\text { Implemented in January } \\
2016\end{array}$ \\
\hline $\begin{array}{l}\text { Standards for financial } \\
\text { market infrastructure }\end{array}$ & $\begin{array}{l}\text { Harmonize with international } \\
\text { standards }\end{array}$ & $\begin{array}{l}\text { Recognized payment } \\
\text { system, securities } \\
\text { settlement systems, } \\
\text { and recognized } \\
\text { clearinghouse ( } \mathrm{RCH})\end{array}$ & $\begin{array}{l}\text { April 2013, with full } \\
\text { implementation by } \\
\text { 2018-19 }\end{array}$ \\
\hline $\begin{array}{l}\text { Deposit Guarantee } \\
\text { Scheme Directive (DGSD) }\end{array}$ & $\begin{array}{l}\text { Prevent depositors from } \\
\text { making panic withdrawals from } \\
\text { banks }\end{array}$ & $\begin{array}{l}\text { Banks, building } \\
\text { societies, and credit } \\
\text { union }\end{array}$ & July 2015 \\
\hline $\begin{array}{l}\text { Central Securities } \\
\text { Depositories Regulation } \\
\text { (CSDR) }\end{array}$ & $\begin{array}{l}\text { Harmonize the authorization } \\
\text { and supervision of EU CSDs and } \\
\text { certain settlement aspects, } \\
\text { such as timing and conduct of } \\
\text { securities settlement }\end{array}$ & $\begin{array}{l}\text { An institution that } \\
\text { holds financial } \\
\text { instruments, including } \\
\text { equities, bonds, money } \\
\text { market instruments, } \\
\text { and mutual funds }\end{array}$ & $\begin{array}{l}\text { September 2014, with } \\
\text { full implementation by } \\
2017\end{array}$ \\
\hline $\begin{array}{l}\text { Financial stability } \\
\text { information } \\
\text { power }\end{array}$ & $\begin{array}{l}\text { Improving financial stability by } \\
\text { requiring firms to provide } \\
\text { information or documents that } \\
\text { the PRA considers are, or might } \\
\text { be, relevant to the stability of } \\
\text { one or more aspects of the UK } \\
\text { financial system. }\end{array}$ & PRA regulated firms & June 2014 \\
\hline SIFIs & Targeted outcome & Target & Implementation \\
\hline Designation/categorization & $\begin{array}{l}\text { Identify the different degree of } \\
\text { risk an institution can generate } \\
\text { for the financial system }\end{array}$ & $\begin{array}{l}\text { Banks, building } \\
\text { societies, credit unions, } \\
\text { insurers, and major } \\
\text { investment firms }\end{array}$ & April $2013^{24}$ \\
\hline
\end{tabular}

\footnotetext{
${ }^{22}$ As of October 2016.

${ }^{23} \mathrm{~A}$ building society is a financial institution owned by its members as a mutual organization. It offers banking and related financial services, especially savings and mortgage lending (source: Wikipedia).

${ }^{24}$ The first set of categorization occurred in April 2013 and designation occurred in December 2013.
} 


\begin{tabular}{|c|c|c|c|}
\hline $\begin{array}{l}\text { Stress testing (UK \& EU- } \\
\text { wide stress test) }\end{array}$ & $\begin{array}{l}\text { Assess the system's capital } \\
\text { adequacy in order to enhance } \\
\text { its resilience under stress }\end{array}$ & $\begin{array}{l}\text { Banks, insurance } \\
\text { companies, investment } \\
\text { firms, and CCPs }\end{array}$ & $\begin{array}{l}\text { At the European level, } \\
\text { bank stress testing } \\
\text { started in 2011, } \\
\text { insurance in 2016, CCPs } \\
\text { in } 2016 .{ }^{25} \text { BoE via PRA } \\
\text { started bank stress } \\
\text { testing in 2014; for } \\
\text { insurance, in } 2016\end{array}$ \\
\hline $\begin{array}{l}\text { Bank and Investment Firm } \\
\text { Recovery and Resolution } \\
\text { Directive (BRRD) }\end{array}$ & $\begin{array}{l}\text { Plan to orderly manage the } \\
\text { failure of a firm }\end{array}$ & $\begin{array}{l}\text { All financial institutions } \\
\text { within the scope of the } \\
\text { resolution regime }{ }^{26}\end{array}$ & $\begin{array}{l}\text { To be implemented by } \\
2018 \text {. However BoE on } \\
\text { November } 2016 \text { set the } \\
\text { Minimum Requirement } \\
\text { for own funds and } \\
\text { Eligible Liabilities (MREL) } \\
\text { to be implemented by } \\
2022^{27} \text {. }\end{array}$ \\
\hline $\begin{array}{l}\text { Consumer/investor } \\
\text { protection }\end{array}$ & Targeted outcome & Target & Implementation \\
\hline $\begin{array}{l}\text { Markets in Financial } \\
\text { Instruments Directive II } \\
\text { (MiFID II) and the } \\
\text { Markets in Financial } \\
\text { Instruments Regulation } \\
\text { (MiFIR) }\end{array}$ & $\begin{array}{l}\text { Improve the competitiveness of } \\
\text { EU financial markets by creating } \\
\text { a single market for investment } \\
\text { services and activities and by } \\
\text { harmonizing protection for } \\
\text { investors in financial } \\
\text { instruments }\end{array}$ & $\begin{array}{l}\text { Investment services } \\
\text { and trading venues }\end{array}$ & $\begin{array}{l}\text { MiFIR: July 2014, but } \\
\text { technical standards need } \\
\text { to be approved; MiFID II: } \\
\text { by } 2018\end{array}$ \\
\hline $\begin{array}{l}\text { Client assets protection } \\
\text { regime (CASS) }\end{array}$ & $\begin{array}{l}\text { Protect customers' money and } \\
\text { assets as fundamental to } \\
\text { consumers' rights }\end{array}$ & $\begin{array}{l}\text { Banks, brokers, asset } \\
\text { managers, investment } \\
\text { firms }\end{array}$ & June 2014 \\
\hline Pension reform & $\begin{array}{l}\text { Secure an appropriate degree of } \\
\text { protection for consumers, } \\
\text { promote effective competition } \\
\text { in the interest of consumers }\end{array}$ & $\begin{array}{l}\text { Every individual or firm } \\
\text { providing pensions and } \\
\text { retirement services or } \\
\text { information and } \\
\text { consumer } \\
\text { representative bodies }\end{array}$ & April 2016 \\
\hline
\end{tabular}

\footnotetext{
${ }^{25}$ By EBA, EIOPA, and ESMA, respectively.

${ }^{26}$ The bank has the responsibility for the resolution of a failing bank, building society, or investment firm and its group companies. CCPs are also seeking a resolution plan through the 2012 CPMI-IOSCO Principles for Financial Market Infrastructure, as implemented within the EU by EMIR.

${ }^{27} \mathrm{MREL}$ is a requirement under the EU Bank Recovery and Resolution Directive. The new rules will be introduced in two phases. Banks will be obliged to comply with interim requirements by 2020. From 1 January 2022, the largest UK banks will hold sufficient resources to allow the Bank of England to resolve them in an orderly way.
} 


\begin{tabular}{|c|c|c|c|}
\hline Mortgage Market Rule & $\begin{array}{l}\text { Allow regulators to deal with } \\
\text { firms that adopt high-risk } \\
\text { strategies and intervene where } \\
\text { business models and strategies } \\
\text { create undue risks for firms, } \\
\text { consumers, and the financial } \\
\text { system generally }\end{array}$ & $\begin{array}{l}\text { Mortgage lenders and } \\
\text { administrators }\end{array}$ & April 2014 \\
\hline $\begin{array}{l}\text { Temporary Product } \\
\text { Intervention Rule }\end{array}$ & $\begin{array}{l}\text { Protect consumers in the shor } \\
\text { term while allowing either the } \\
\text { FCA or industry to develop a } \\
\text { more permanent solution }\end{array}$ & FCA's authorized firms & April 2013 \\
\hline $\begin{array}{l}\text { Market integrity and } \\
\text { derivatives dealing }\end{array}$ & Targeted outcome & Target & Implementation \\
\hline Ring fencing & $\begin{array}{l}\text { Separate certain retail } \\
\text { banking activities into } \\
\text { separate entities within } \\
\text { the corporate group. } \\
\text { These ring-fenced bodies } \\
\text { are then prohibited from } \\
\text { carrying out certain } \\
\text { activities, including } \\
\text { dealing in investments as } \\
\text { principal }\end{array}$ & $\begin{array}{l}\text { Institutions that have } \\
\text { more than } f 25 \text { billion of } \\
\text { "core deposit"-broadly, } \\
\text { those from individuals and } \\
\text { small businesses-on } \\
\text { average, over a period of } \\
\text { three years }\end{array}$ & January 2019 \\
\hline $\begin{array}{l}\text { European Market } \\
\text { Infrastructure Regulation } \\
\text { on derivatives, central } \\
\text { counterparties, and trade } \\
\text { repositories (EMIR) }\end{array}$ & $\begin{array}{l}\text { Reduce counterparty risk } \\
\text { that can become systemic, } \\
\text { implementing new risk } \\
\text { management standards, } \\
\text { including reporting } \\
\text { requirement, and } \\
\text { operational processes, for } \\
\text { all bilateral over-the- } \\
\text { counter derivatives }\end{array}$ & $\begin{array}{l}\text { OTC derivatives, central } \\
\text { counterparties, and trade } \\
\text { repositories }\end{array}$ & $\begin{array}{l}\text { April 2014, with full } \\
\text { implementation by } 2019\end{array}$ \\
\hline $\begin{array}{l}\text { Alternative Investment } \\
\text { Fund Managers Directive } \\
\text { (AIFMD) }\end{array}$ & $\begin{array}{l}\text { Increase transparency by } \\
\text { AIFMs and data sharing } \\
\text { with relevant regulators to } \\
\text { efficiently monitor } \\
\text { financial systems in the } \\
\text { EU; also is intended to } \\
\text { protect investors }\end{array}$ & $\begin{array}{l}\text { Hedge funds and private } \\
\text { equity }\end{array}$ & $\begin{array}{l}\text { June } 2013 \text {, with full } \\
\text { implementation by } 2018\end{array}$ \\
\hline $\begin{array}{l}\text { Senior Managers Regime } \\
\text { (SMR) and Senior } \\
\text { Insurance Managers } \\
\text { Regime (SIMR) }\end{array}$ & $\begin{array}{l}\text { Ensure personal } \\
\text { accountability of senior } \\
\text { management in case of } \\
\text { professional misconducts }\end{array}$ & $\begin{array}{l}\text { Banks, building societies, } \\
\text { credit unions, and PRA- } \\
\text { designated investment } \\
\text { firms and insurance } \\
\text { companies }\end{array}$ & $\begin{array}{l}\text { March } 2016 \text {, to be applied } \\
\text { to "all" registered financial } \\
\text { firms by } 2018\end{array}$ \\
\hline $\begin{array}{l}\text { Undertakings for } \\
\text { Collective Investment in } \\
\text { Transferable Securities } \\
\text { Directive (UCITS V) }\end{array}$ & $\begin{array}{l}\text { Strengthen the level of } \\
\text { protection for investors in } \\
\text { UCITS and harmonize the } \\
\text { level of supervision by EU } \\
\text { regulators }\end{array}$ & $\begin{array}{l}\text { Mutual funds and } \\
\text { alternative investment } \\
\text { funds }\end{array}$ & March 2016 \\
\hline
\end{tabular}




\section{References}

Adams-Kane, Jonathon, Claude Lopez, and Jakob Wilhelmus, "Cross-Border Investment in Europe: From Macro to Financial Data," Milken Institute Publications, 2016.

Bank for International Settlements, "86th Annual Report," BIS Publications, June 2016.

Bank for International Settlements, Financial Stability Board and International Monetary Fund, "Elements of Effective Macroprudential Policies, Lessons from International Experience," IMF-FSB-BIS Joint Publications, August 2016.

Bank of England, "Financial Stability Report," Bank of England Publications, July 2016.

Bax, Laurence and William Wright, "What Do EU Capital Markets Look Like Post-Brexit?" New Financial Publications, September 2016.

Carney, Mark, "The Future of Financial Reform," Bank of England Publications, November 2014.

Coen, William, "Finalizing Basel III, Secretary General of the Basel Committee," meeting of the European Parliament's Committee on Economic and Monetary Affairs (ECON Committee), October 2016.

Council of the European Union, Economic and Financial Affairs, Outcome of the EU Finance Ministers Meeting, July 2016.

Dombrovskis, Valdis, speech at the European Banking Federation Conference, September 2016.

European Systemic Risk Board, "Macroprudential Policy Beyond Banking: An ESRB Strategy Paper," ESRB Publications, July 2016.

European Insurance and Occupational Pensions Authority, European Banking Authority and European Securities and Markets Authority, "Risks and Vulnerabilities in the EU Financial System," Joint Committee Report, August 2016.

European Central Bank, "Financial Integration in Europe," ECB Publications, April 2016.

Financial Stability Board, "Proposed Policy Recommendations to Address Structural Vulnerabilities from Asset Management Activities, Consultative Document," June 2016.

Financial Stability Board, "Implementation and Effects of the G20 Financial Regulatory Reforms," FSB annual report, August 2016.

Financial Stability Board, "Key Attributes Assessment Methodology for the Banking Sector," FSB Publications, October 2016.

Financial Policy Committee, record of the Financial Policy Committee Meeting, September 2016.

Fisher, Paul, "The Financial Regulation Reform Agenda: What Has Been Achieved and How Much Is Left to Do?" Bank of England Publications, September 2015.

General Court of the European Union, press release No. 29/15, March 2015. 
Lehmann, Matthias, "Volcker Rule, Ring-Fencing or Separation of Bank Activities: Comparison of Structural Reform Acts Around the World," LSE Law, Society and Economy Working Papers 25/2014, 2014.

Lopez, Claude and Elham Saeidinezhad, "Dodd-Frank: Washington, We Have a Problem," Milken Institute Publications, July 2016.

Prudential Regulation Authority, "The Financial Stability Information Power Statement of Policy," Bank of England Publications, June 2014.

"Record of the FPC Meetings," Bank of England Publications, June 28 and July 1, 2016.

"Record of the FPC Meetings," Bank of England Publications, September 2016.

Scarpetta, Vincenzo and Stephen Booth, "How the UK's Financial Services Sector Can Continue Thriving After Brexit," Open Europe Publications, October 2016.

Tarullo, Daniel, speech at the Yale University School of Management Leaders Forum, New Haven, Connecticut, September 2016.

"TheCityUK: UK Financial and Related Professional Services: Meeting the Challenges and Delivering Opportunities," TheCityUK Publications, August 2016.

Wright, William, "If I Ruled the World: A Wish List for Unlocking Capital Markets In Europe," New Financial Publications, September 2015. 
14 | P a g e 